\title{
THE FINER STRUCTURE OF SYNAPSES AND NEURONES
}

\author{
A Review of Recent Electronmicroscopical Studies \\ By P. Glees, M.A., D.Phil.(Oxon), M.D. and K. Meller, M.D. \\ Institut für Histologie und experimentelle Neuroanatomie der Universität, Göttingen
}

\section{INTRODUCTION}

So much progress has been made recently by exploring the nervous system with the help of electronmicroscopy that it is justified to present to the clinical neurologist a short review of some of the advances made. The aim of this survey, limited to the intracellular structures of synapses and the nerve cell, is to convey some neuroanatomical results to clinical neurology and by this to general medicine.

The main progress brought about by electronmicroscopy is the disclosure of highly organised intracellular organelles of the nerve cells and the detailed morphological features of synapse, particularly the synapses found in the cerebellar and cerebral cortex. Finally, some of our results dealing with the developing of the nervous system will be described to illustrate that considerable progress in the understanding of nervous organisation can be expected from the electronmicroscopic study of the maturing nervous system.

For technical reasons we review mainly the synapses and intracellular structures of large cells. In this way we follow neurophysiological progress, which was bound to take place on large nerve cells, for it is technically easier for microelectrodes to penetrate large cells. It is also morphologically easier to reconstruct features of large cells in the cerebellum, cerebral cortex and spinal cord when viewed under the electronmicroscope.

\section{THE PURKINJE-CELL AS A MODEL FOR SYNAPTIC STUDIES}

Much progress has been made on the finer structures of large cells of the cerebellar cortex which were described for the first time by Purkinje at a congress in Prague in I837. This is one of the earliest descriptions of nerve cells, and the relatively accurate description of this cell deserves mentioning if one considers the primitive neurohistological technique of his time (Liddell, 1960). Further and decisive progress on the structure of Purkinje-cells were made by Ramon y Cajal (I952) who employed the Golgi-technique in the most skilful way. With this technique the richly branching Purkinje-cell can be divided in three main sections: the dendrites, the cell body and the axon (fig. I). This polar arrangement, dendrites branching profusely in one direction of the cell body, while the axon emerges from the opposite pole of the cell, gave Cajal the concept of fundamental differences between these two types of processes. Cajal assumed that the dendrites were the receptive pole of the nerve cell and the axon the conducting portion. This concept was ingenious and fruitful but could only quite recently be proved conclusively by electronmicroscopy. For the dendrites viewed in lightmicroscopy seemed to be immersed into the molecular layer of the cerebellum without making obvious and distinct contacts with other nerve fibres. Already Cajal had proposed that incoming impulses were carried by climbing fibres (fig. 2) which wind around dendrites of Purkinje-cells and between dendrites and other nerve fibres, more or less meeting each other at right angle. Fox and Barnard (1957) by repeating Golgi's technique 
on cerebellar tissue estimated that one dendrite of a Purkinje-cell might have more than 60,000 synaptic contacts and that 300,000 nerve fibres could have synapses with one Purkinje-neurone. He further stressed the possibility that one carrier of these synapses might be the fine protrusions which cover the dendritic processes of the Purkinje-cells (fig. I, right insert). Glees et al. (1958) have studied the various types of synapses of the cerebellum of the frog with silver stain. But only the electronmicroscopical studies by Gray (1961, I962) and Herndon (1963) brought about more definite knowledge of Purkinje-synapses and could establish that the fine protrusions of the dendrites (also called Golgi-thorns) were in fact synaptic processes (fig. I, left insert, sp.).

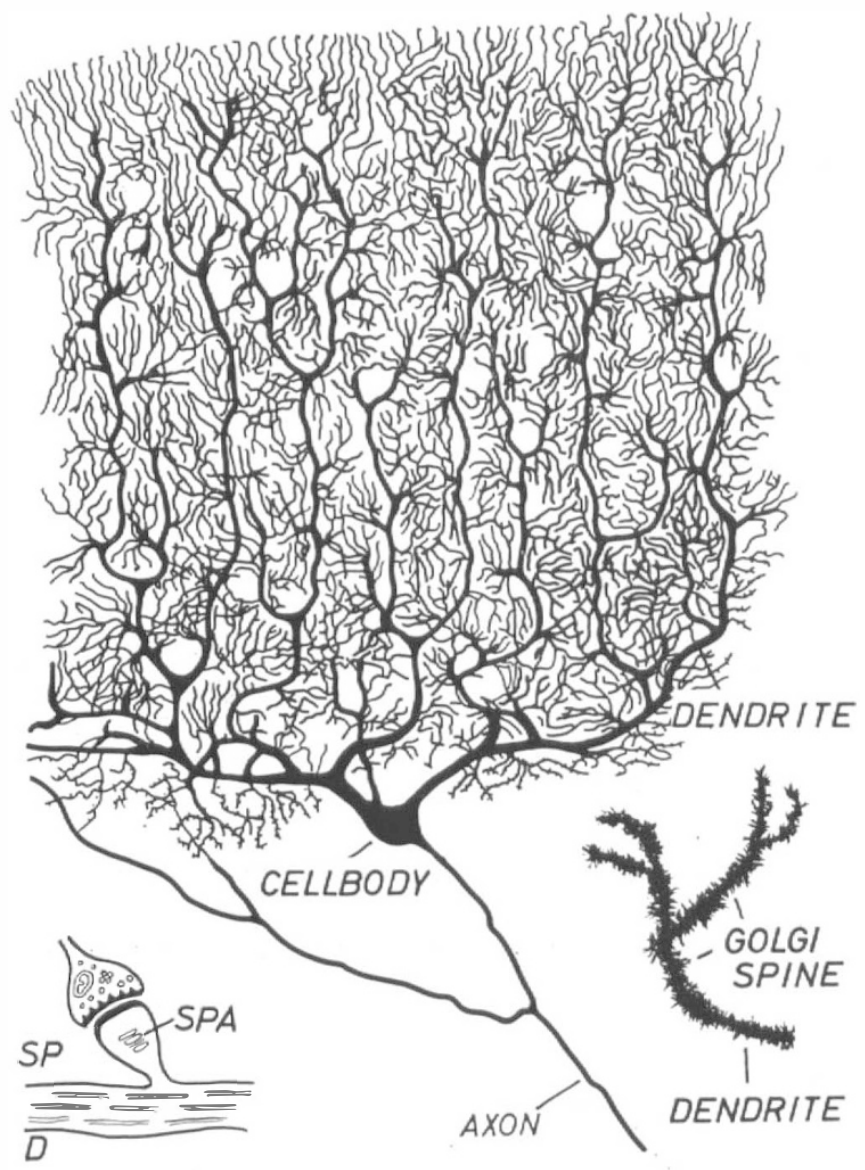

FIG. I

A Purkinje-neurone, Golgi-impregnation, which shows all the dendritic branches. Redrawn after Cajal. Insert in lower right corner shows a dendritic branch covered with fine Golgispines. Lower left corner one Golgi-spine protruding from a dendrite $=\mathrm{D}$, showing the spine apparatus $=\mathrm{SPA}$, in synaptic contact with a presynaptic fibre containing small synaptic vesicles and a mitochondrium (diagram). 
The Purkinje-cell has not only served as a useful model for the polar arrangement of nerve cells, but has also been helpful in discriminating general types of contact between terminating fibres and dendrites, the axo-dendritic synapses, and the contact made by terminating fibres with the cell body the axo-somatic type. This differentiation had also been clearly predicted by Cajal, who showed that the cell body of the Purkinje-cell has a different type of neuronal junction from the dendrites, for the cell body was closely enveloped by the clubshaped endings of the

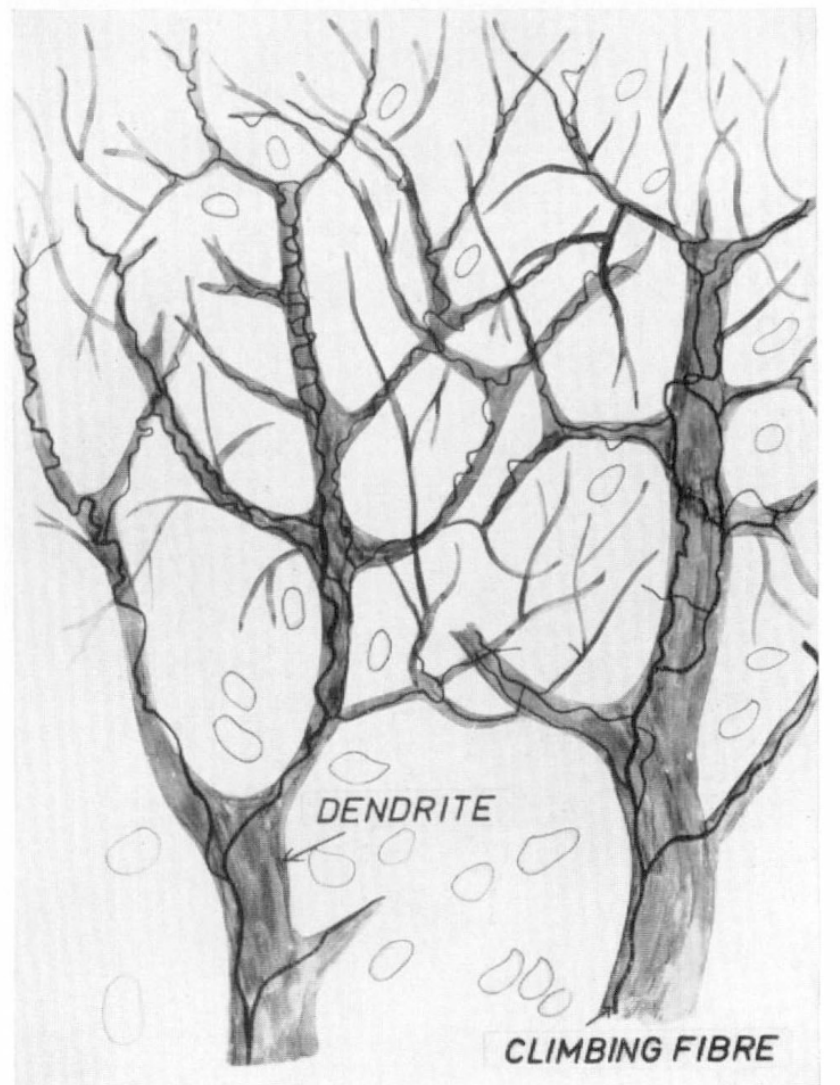

FIG. 2

The Purkinje-dendrites are wrapped in by fine fibres, this is a contact between two portions of a neurone, called by Cajal parallel contact of axo-dendritic type.

basket fibres (fig. 3). Electronmicroscopical studies of the axo-dendritic synapses have shown that the Golgi-thorns are spinelike protrusions, containing a special feature, the spine apparatus, and that the membrane in contact with terminating nerve fibres is specially thick and has properties of a post-synaptic membrane. This post-synaptic membrane can also be divided into several segments and is in intricate contact with the pre-synaptic membrane which is a portion of the membrane enclosing the terminal portion of the efferent nerve fibre. This terminating 
portion contains within its baglike structure mitochondria and numerous vesicles called synaptic vesicles (Gray \& Whittaker, I960) because they probably contain the transmitter substance and mitochondria. These synaptic vesicles are relatively small and have an average size of $3 \mathrm{~m} \mu$ (fig. $4 a$ ). The space between pre- and postsynaptic membrane varies between 2 and $3 \mathrm{~m} \mu$, and under high resolution electronmicroscopy appears to be filled with an electrodense substance which has been

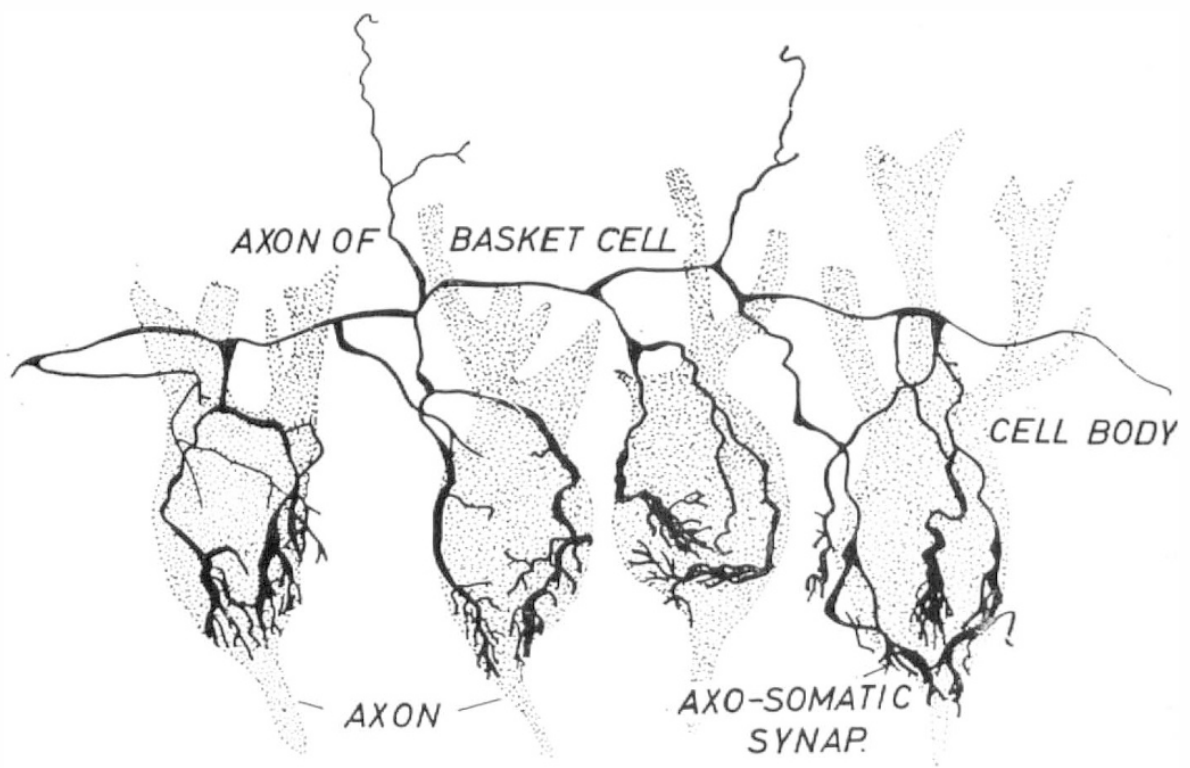

FIG. 3

Axo-somatic contacts of terminating axons with the cell body of a Purkinje-neurone are established by an axon of a basket cell. Redrawn and modified from Cajal.

referred to as 'cementing substance'. We believe from our recent observations on synaptic structures that this cementing substance is not an amorphous filling between the neural membranes in synaptic contact with each other, but shows a segmental pillar-like arrangement. In fact, high-power electronmicroscopy does not reveal the synaptic gap as an empty intercellular space but rather as a definite structure of complicated architecture (fig. $4 b$ ). How, therefore, the diffusion of iones in impulse transmission can be explained, is difficult to say. It would appear from these findings equally unlikely that synapses can alter their position or greatly enlarge their contacting surfaces. This view finds further confirmation by the findings of Gray and Whittaker that pre- and post-synaptic membranes cannot be separated in centrifuged subcellular particles of brain tissue. For the interdigitating types of synapses seen in the cerebral cortex or in the retina appear to prevent synaptic displacement. We may finally mention for comparative purposes that synaptic vesicles have been found in all functional terminations of nerve fibres, e.g. the motor endplate, the minute endplate of autonomic fibres and in the termination of hypothalamic fibres in the posterior lobe of the pituitary gland. 


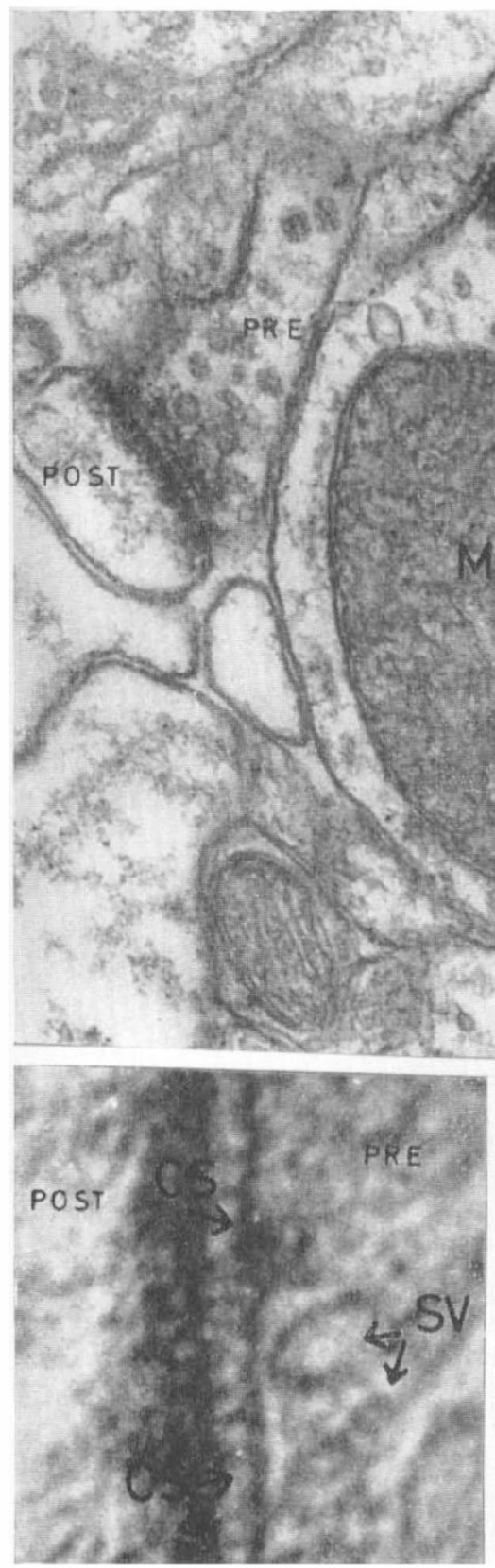

b

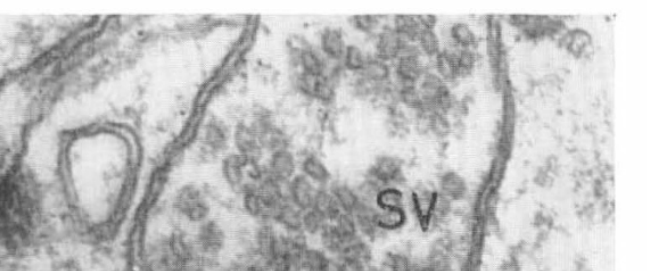


Synapses in the Cerebral Cortex. Electronmicroscopical studies of the cerebral cortex proved to be specially important (Horstmann, 1957; Niessing \& Vogell, I960; Gray, I962; Van der Loos, 1963), for silver stains fail to reveal synaptic structures in the cerebral cortex. It has been suggested that only if neurofibrillae are present, can synapses be stained with silver. The lack of neurofibrillae in synaptic terminations within the cortex would explain the failure of silver stains. Electronmicroscopy has indeed solved the mystery of cortical synapses, for an abundance of synaptic structures could be revealed with this technique (fig. 5). The dendrites of the cerebral cortex show, like the cerebellar

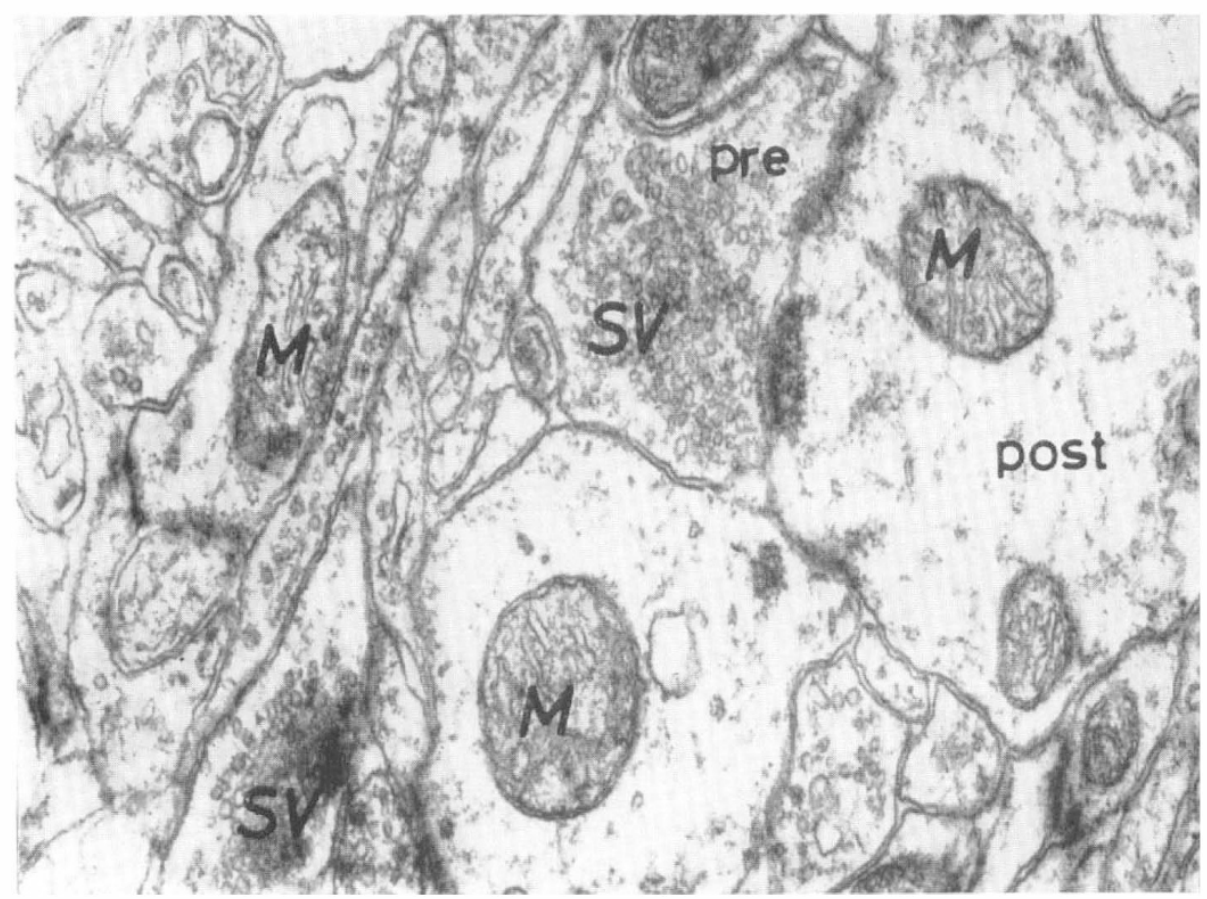

Fig. 5

Axo-dendritic synapses. $M=$ mitochondria, POST = post-synaptic membrane, PRE $=$ pre-synaptic membrane, $\mathrm{SV}=$ synaptic vesicles. Note that the synaptic membranes in contact with each other are divided into two portions and that the synaptic vesicles are more concentrated around the lower portion. $(48,000 \times$.)

neurones, a wealth of post-synaptic spines covered with terminating fibres. With these findings a considerable gap in our knowledge of the mode of intracortical transmission has been closed, and has finally disproved the existence of diffuse cortical grey either in the form of a nerve or the simple form of diffuse contact formations by any given neural membrane in contact with a passing fibre. Electronmicroscopy has definitely established specific and well-defined cortical synapses (fig. 6). 
Development of Synapses. The synaptic development is studied preferentially in our laboratory and some of the results are in the process of being published. Our work concentrates on the development of the chicken nervous system as this material is readily available and its time sequence can be accurately determined. Initially we found the fixation of the embryos very difficult, but this difficulty has now been overcome. It could be ascertained that synapses or at least some of the

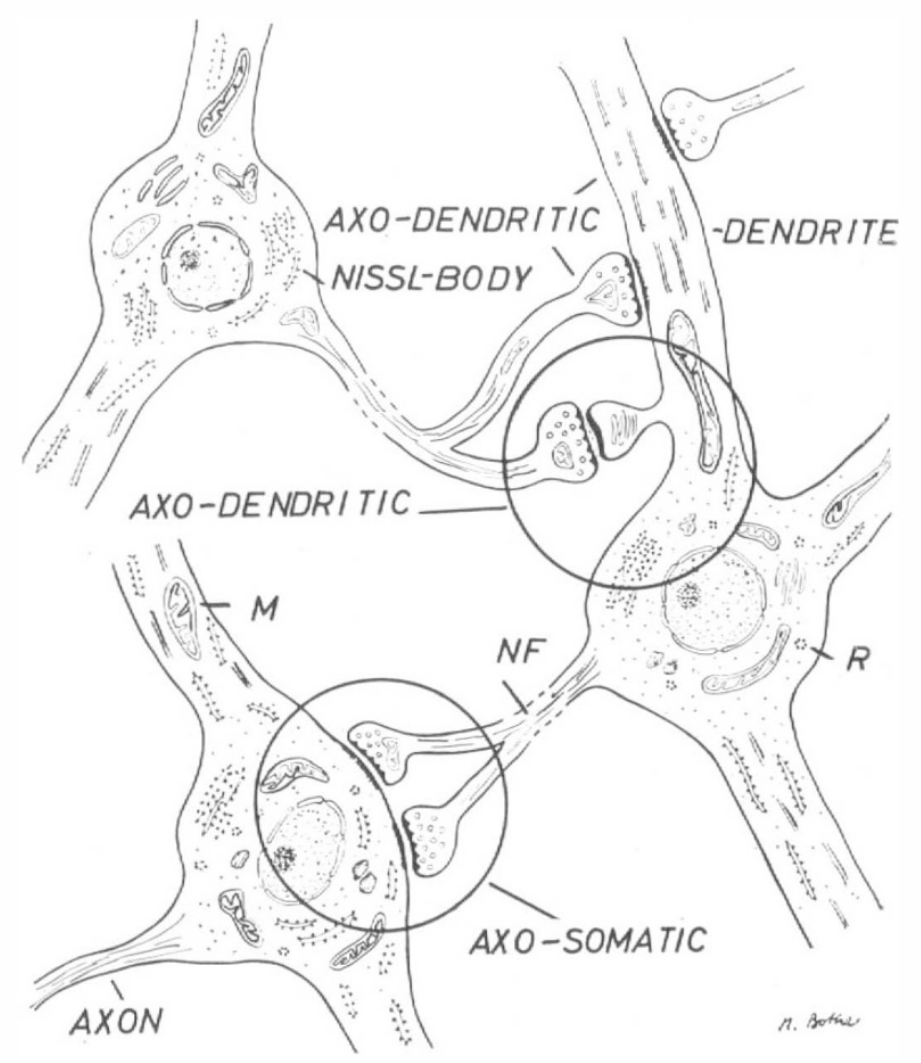

FIG. 6

General diagram of cortical synapse formation and of intraplasmatic organisation of neurones. The upper circle shows an axo-dentritic synapse of the spine type, the lower circle the axo-somatic type. Note that also non-spinous axo-dendritic contacts are present, within the neurone the Nissl-body is illustrated and the free ribosomes in form of rosettes (R). The neurofilaments are present in dendrites and axon.

structures typical for synapses can be seen around the 7th day of incubation (fig. 7). It would appear that synaptic membrane thickening occurs first, and that the other features of synapses such as synaptic vesicles appear later. Around the 15 th day of incubation, morphologically well-defined synapses can be found in some places, e.g. the anterior horn, while another portion of the same section may show only 


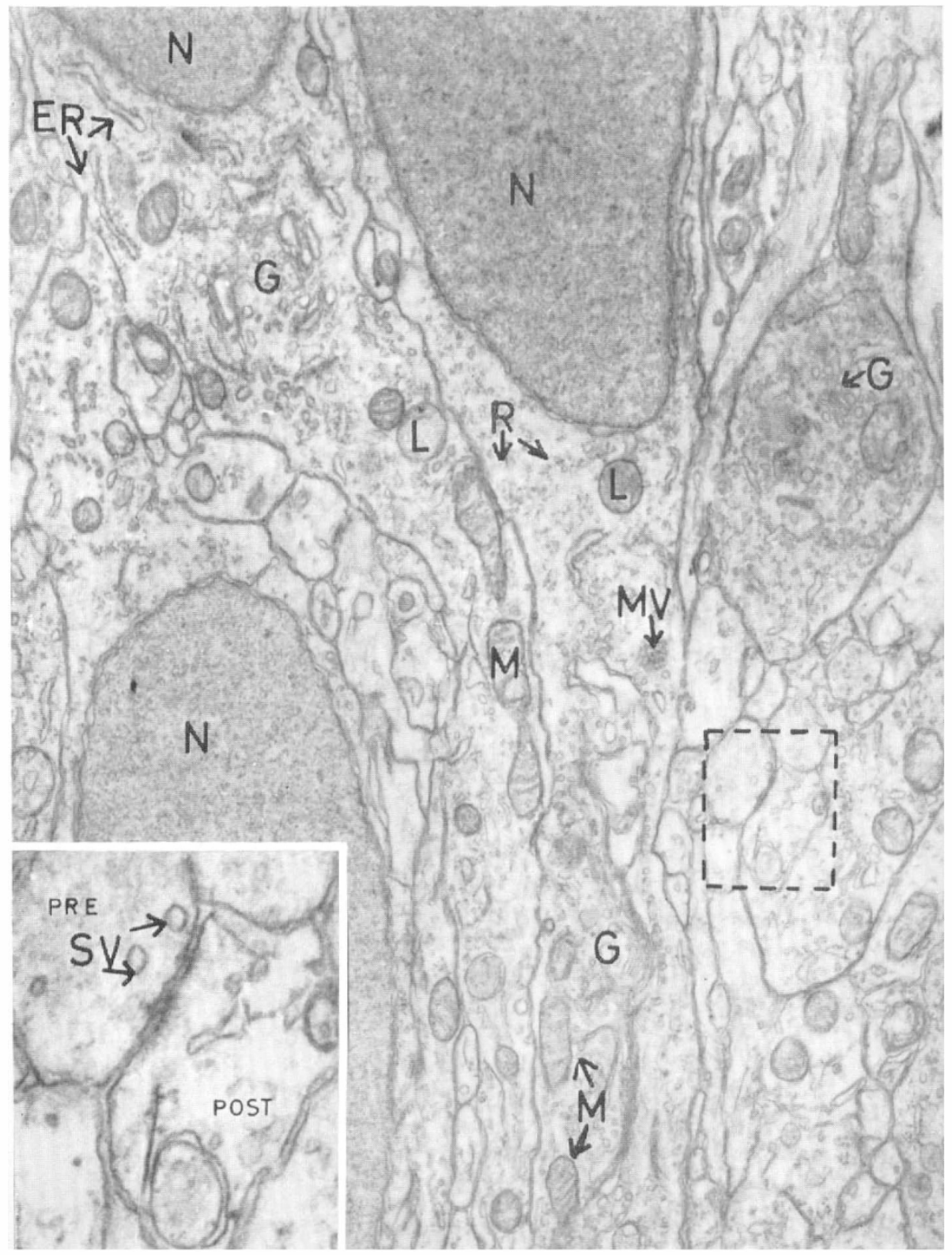

FIG. 7

Section of spinal cord of chick after seven days of incubation. Note the elongated neuroblasts with their nuclei $(\mathrm{N}), \mathrm{I} 4,000 \times, \mathrm{L}=$ lysosomes, $\mathrm{M}=$ mitochondria, $\mathrm{MV}$ $=$ multivesicular body, $\mathrm{G}=$ golgi-apparatus, $\mathrm{ER}=$ endocellular reticulum. Left lower insert, magnified from framed portion of the larger picture shows the developing synapses, $45,000 \times, \mathrm{POST}=$ post-synaptic membrane, $\mathrm{SV}=$ synaptic vesicles. Note the large Golgi-apparatus in contrast to the small amount of the ER and the abundance of free ribosomes. 
primitive synapses (fig. $8 a, b$ ). We are attempting at present to relate the development of synapses to the functional maturation of the nervous system, in particular to the movements controlled by the spinal cord, and also are trying to relate the synaptic development to the maturation of the Nissl-substance. The differentiation of nerve cells, in particular the development of the endoplasmatic reticulum, has been studied (Duncan, I957; Bellaris, I959; Sotelo \& Trujillo-Cenóz, I958; Tennyson, 1962; Eschner \& Glees, 1963; Wechsler \& Meller, 1963) while the cellular organisation of the neural tube, the development of the neuroblast, and that of the mantle zone has been studied by Wechsler and Meller (1963). These authors have paid special attention to the problems of extracellular space and histological maturation in the germinal layer of the neural tube. We can conclude from the observations quoted above that the embryonic cells of the central nervous system have to start with scanty ER but have numerous and free RNS granules. Highly specialised cells such as nerve cells take their origin, like all other cells which combine to form organs, from simple types of cells containing a great amount of RNS granules.

Tracing Nervous Interconnections by identifying Degenerating Synapses. Before concluding the synapse section of this paper some mention must be made of the fact that synapses degenerate in a very characteristic manner when the stem fibre has been cut or after the neurone having given rise to the stem fibre has been metabolically interfered with (fig. 9) (Glees \& Eschner, I962).

The termination of nervous pathways can be established by cutting fibre tracts or destroying the cells of origin of these tracts (Glees \& Nauta, I955). The changes which occur after such lesions on the terminations of nerve fibres are referred to as synaptic degeneration. This type of degenerative change can be studied most clearly in the lateral geniculate body of the monkey when portions of the retina have been destroyed (Glees, Hallermann \& Naeve, 1964) or when the optic nerve has been cut (Glees, I96I). Within three days after injury, the synaptic terminations of optic fibres increase considerably in size, at least ten or fifteen times the normal size, and can be readily stained with silver nitrate (fig. Io). With this method, referred to as the bouton-method, accurate location of terminating fibres within the C.N.S. has been made (Bowsher et al., I960; Brodal \& Grant, I962). The phenomenon of bouton or synaptic degeneration has also been studied with the help of electronmocroscopy (Gray \& Hamlyn, I962; Colonnier \& Gray, 1962; Guillery, I964; Glees \& Meller, unpublished). Apart from the gross swelling of synapses, seen in lightmicroscopy, very characteristic signs of degeneration are visible in the synaptic bag such as increase in neurofilaments, swelling of mitochondria and an accumulation of synaptic vesicles, when examined by electronmicroscopy. The observed changes seem to indicate that protein synthesis is still occurring in the terminal portion of a nerve fibre although it has been severed from its trophic centre, the nerve cell. From these few examples it can be seen that electronmicroscopy, after surmounting the initially difficult problem of fixation, has come to stay as a fruitful method of morphological investigation of the C.N.S.

\section{INTRACELLULAR ORGANISATION OF THE NERVE CELL}

We limit our description to the spinal motoneurone and large cortical neurones not only for the reason referred to in the introduction, namely the large size of the 

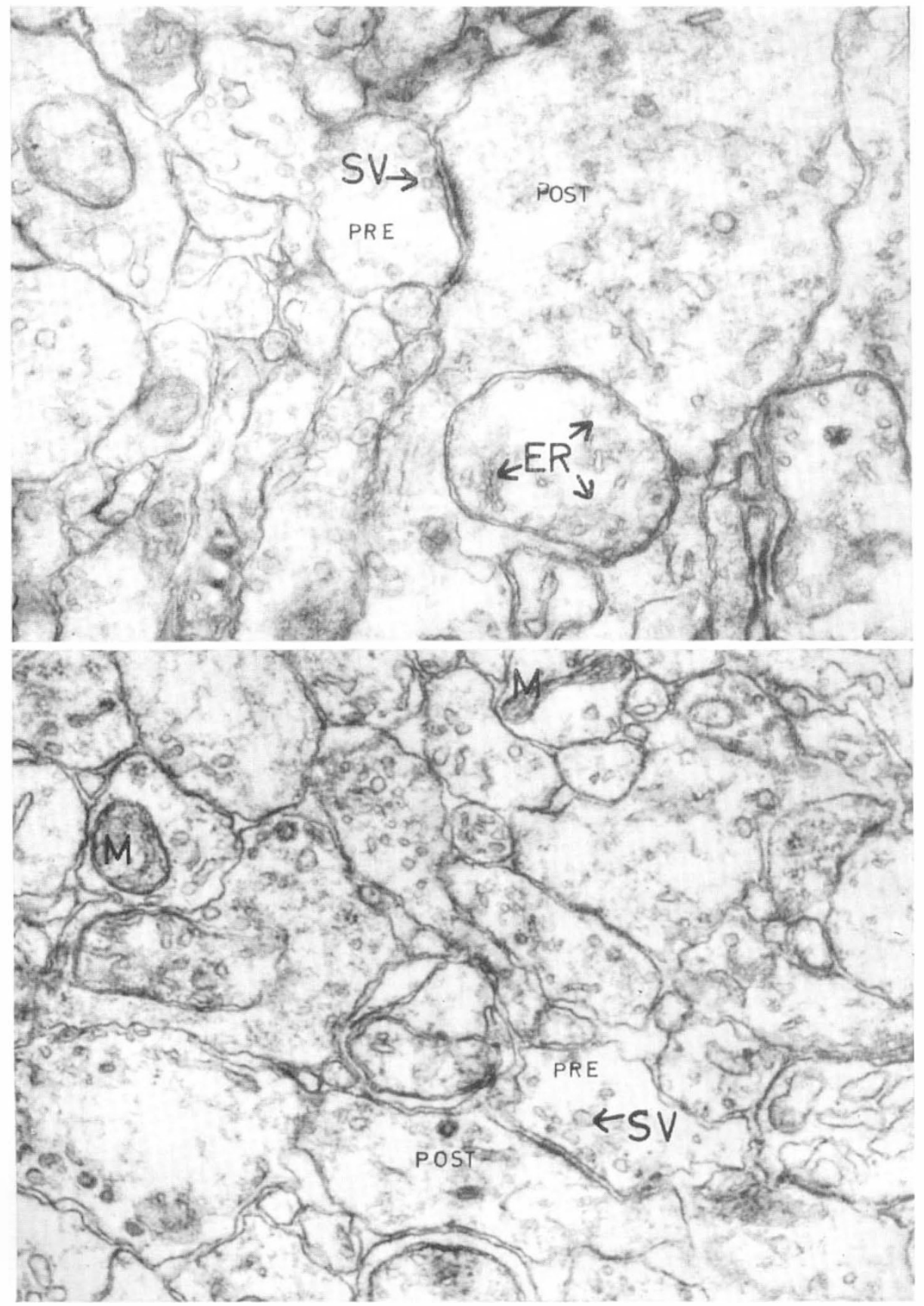

FIG. 8

Upper picture shows synaptic development in the chick spinal cord, Ioth day of incubation. $40,000 \times$. The lower picture is synapse, 15 th day of incubation. $E R=$ endocellular reticulum, $\mathrm{M}=$ mitochondria, $\mathrm{POST}=$ post-synaptic membrane, $\mathrm{PRE}=$ presynaptic membrane. 


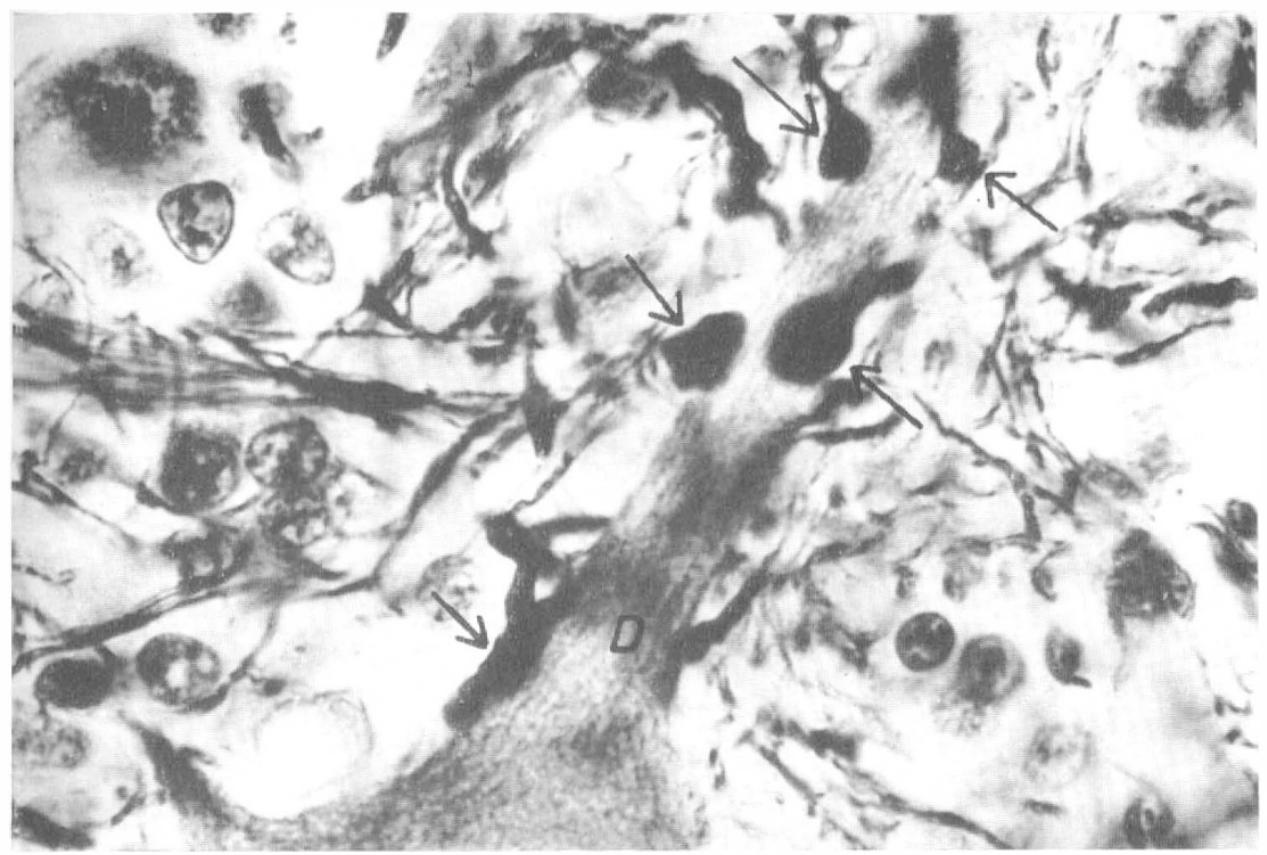

FIG. 9

Dendritic portion of a spinal neurone covered with enlarged degenerating synapses marked by arrows. The degeneration of synapses occurred after tri-cresyl-phosphate poisoning, $\mathrm{D}=$ dendrite. To the left and right of the dendrite are neuroglia nuclei and branching axons. (Glees silver impregnation.)

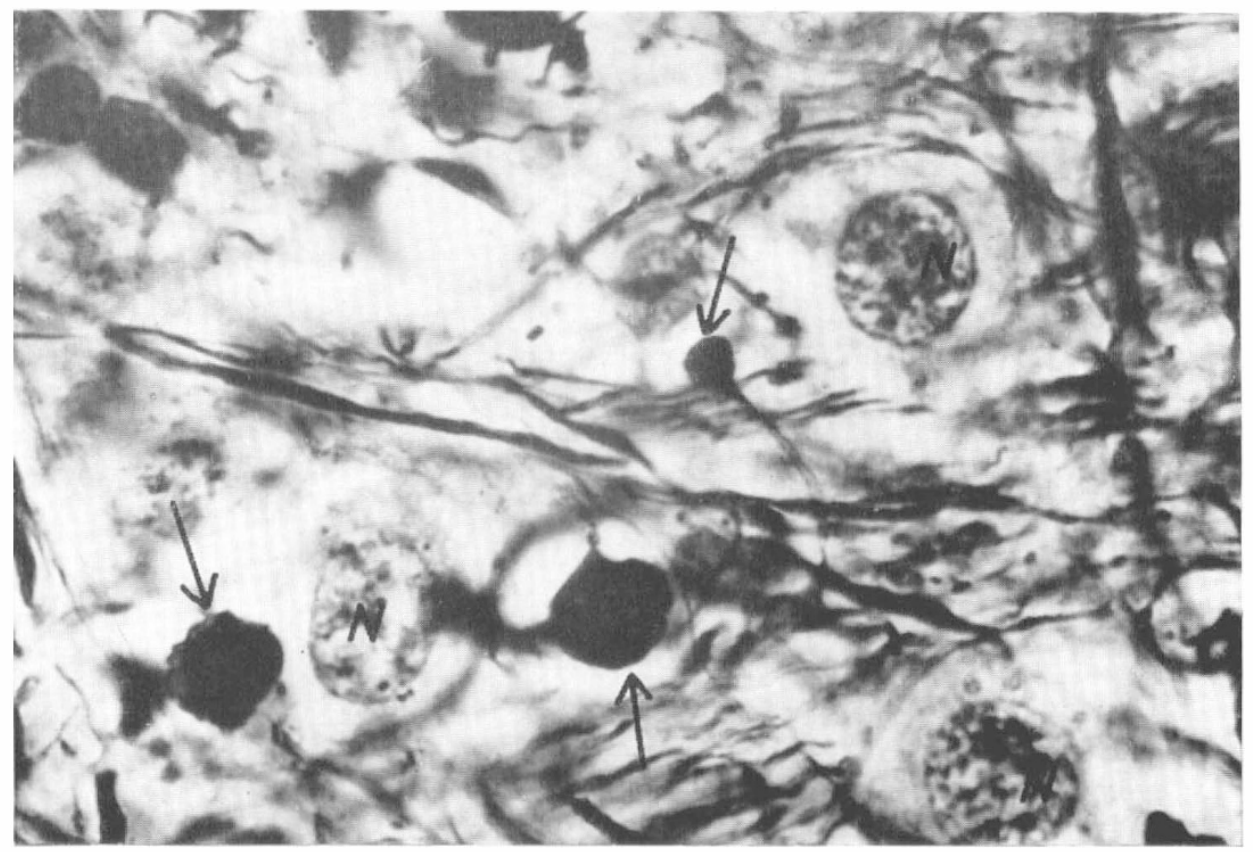

FIG. IO

Section through lateral geniculate body of the monkey showing synaptic degeneration, following sectioning of one optic nerve. $\mathbf{N}=$ nuclei of neurones (post-synaptic neurones). Arrows mark the enlarged optic synapses. (Glees silver impregnation.) 
cell, but also because our present studies are concentrated on the organisation of the developing spinal cord. The motoneurone shows a large Golgi-apparatus (Honjin, 1956; Lacy, 1957; Thomas, 1960) which in the thin sections used for electronmicroscopy is cut in various angles (fig. II). Its lumen is larger than that of the ER, and in contrast to it, the walls are not covered by ribosomes. The function of this large intracellular structure in nerve cells is unknown, while in gland cells it takes part in the synthesis of the secretory granules. The fact that the Golgi-apparatus is very often found near the nucleus may indicate its import-

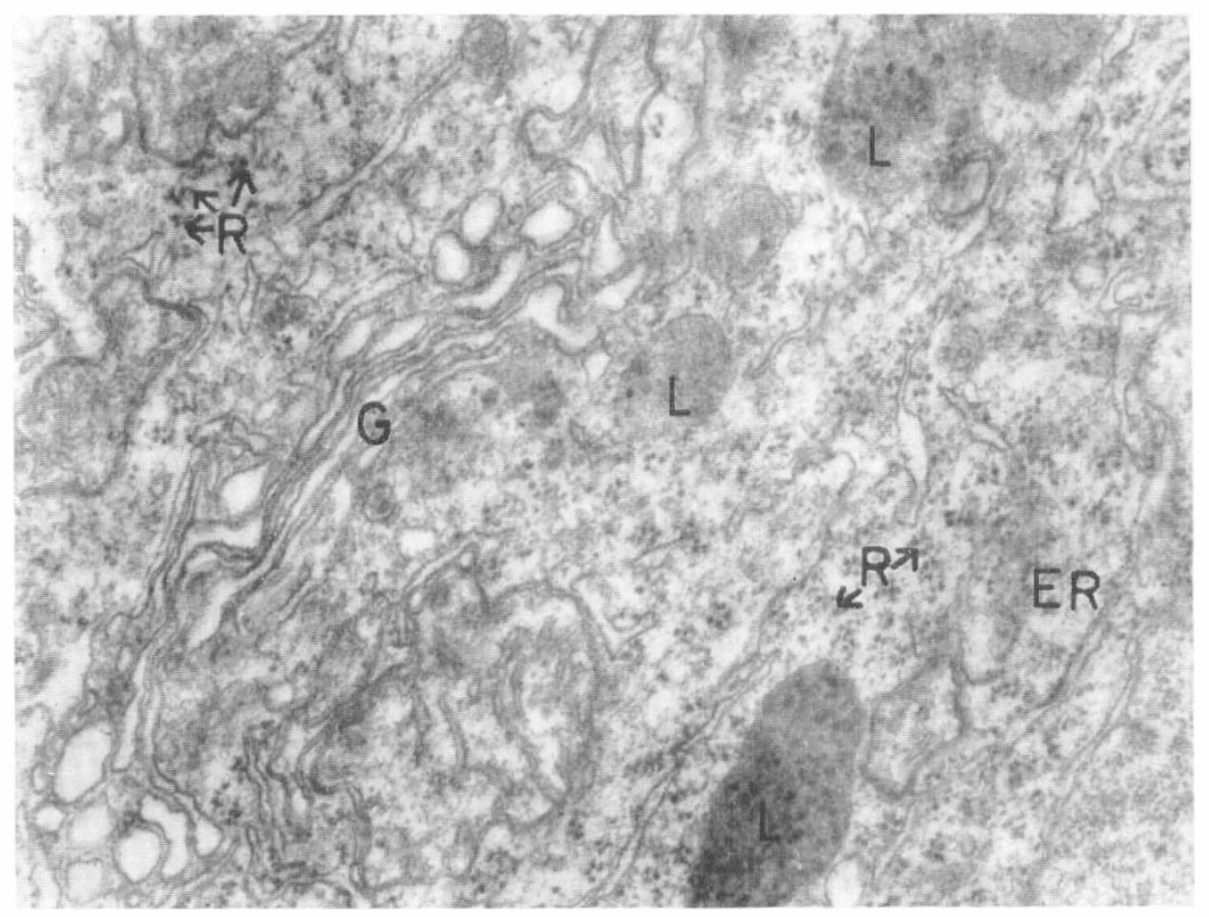

FIG. I I

Cerebral cortex of the rat portion of one large neurone show endoplasmatic reticulum $=\mathrm{ER}$, golgi-apparatus $=\mathrm{G}$, lysosomes $=\mathrm{L}$, and numerous ribosomes in form of rosettes $=\mathbf{R}$.

ance for protein synthesis (Zeigel \& Dalton, 1962). It is most likely that there is a functional relationship of Golgi-apparatus and ER. It is possible that the smaller tubules of the Golgi-apparatus represent really only an agranular form of the ER. Wechsler and Meller (1963) have found that immature nerve cells (neuroblasts) already have a well-developed Golgi-complex when the ER is still incompletely developed (fig. 7). This deserves attention, for the protein synthesis at this stage of intense cellular process formation points to the possibility that protein synthesis should not be exclusively related to the ER. It must be pointed out, too, that injury to the motoneurones of the spinal cord by cutting nerve roots or due to a spinal trauma causes marked alteration of the Golgi-apparatus. This change can be 
accompanied by alterations in the ER (chromatolysis) which is usually considered to be a demand for protein synthesis in order to regenerate cell processes. This need not, however, be the only explanation. Frequently older nerve cells show electrodense inclusion bodies, which may represent pigment or lipoid material (fig. I2).

A further intracellular feature in electronmicroscopical pictures of nerve cells are the distinct neurofilaments which present subunits of the neurofibrillae seen in light microscopy. Neurofilaments are found in dendrites, cell body and axon (Thornburg \& de Robertis, I956; Eichner, I956; Schmitt, I957).

The Finer Structure of the Nissl-body. The familiar picture of Nisslbodies seen in lightmicroscopy is depicted in Figure I3, and Figures I4 and I 5 and illustrate the recent advance made by electronmicroscopy, dealt with in the following pages.

The structure of the Nissl-body will be considered in some detail, for one of us (P. G.) has suggested that there is some indirect evidence that this structure might be utilised for the storage of electro-chemical events and by this form the basis of memory deposition on a molecular basis (Hyden, I96I; Eschner \& Glees, 1963). The Nissl-substance is biochemically composed of ribonucleic acid (RNA) which is widely distributed in granular form in the cytoplasm of nerve cells. Electronmicroscopy and biochemical analysis have shown that RNA is distributed in two ways within the cell. One mode of distribution is the scattering of RNA granules within the cytoplasm of the cell (fig. I4). Many of these granules are grouped together to form a rosette-like arrangement. A considerable number of ribosomes have, however, a more orderly arrangement (fig. I5) by being attached to the walls of narrow cavities (Palade, I955; Smith, 1959). These cavities form flat cisternae which intercommunicate through fine tubuli showing vesicular dilatations. The membranes of these cavities, referred to as endoplasmatic reticulum, are very thin, 6 to $7 \mathrm{~m} \mu$, and the width of these cisternae varies between 30 and $50 \mathrm{~m} \mu$ (Palay \& Palade, I955). The ribosomes not bound to the membranes of the ER have also been called microsomes by biochemists who obtain them by centrifuging liver cells. (Palade \& Siekevicz, I956). In this connection it is worth while mentioning that liver cells and nerve cells have much in common on account of the presence of free and membrane-bound ribosomes, and when suitably stained will give histochemically similar pictures under light and electronmicroscopy. Not only the cytoplasm of these two functionally very different types of cells shows similarity, but also the nucleus, which in both instances is specially large and electrondense. Liver cells studied electronmicroscopically have structures resembling the Nissl-bodies in having a great wealth of membrane-bound ribosomes which give the liver cells a basophilic staining. Structurally there seems to be one difference between liver cells and nerve cells. The mitochondria in liver cells are probably more numerous, while in nerve cells mitochondria seem to be distributed more densely between individual Nissl-bodies. Of course, there is one marked morphological difference between liver and nerve cells. Only the latter show dense arborations. However, apart from the axon, all the other processes of the nerve cell, all of which are called dendrites, are essentially expansions of the cytoplasm and contain granular endoplasmatic reticulum. 


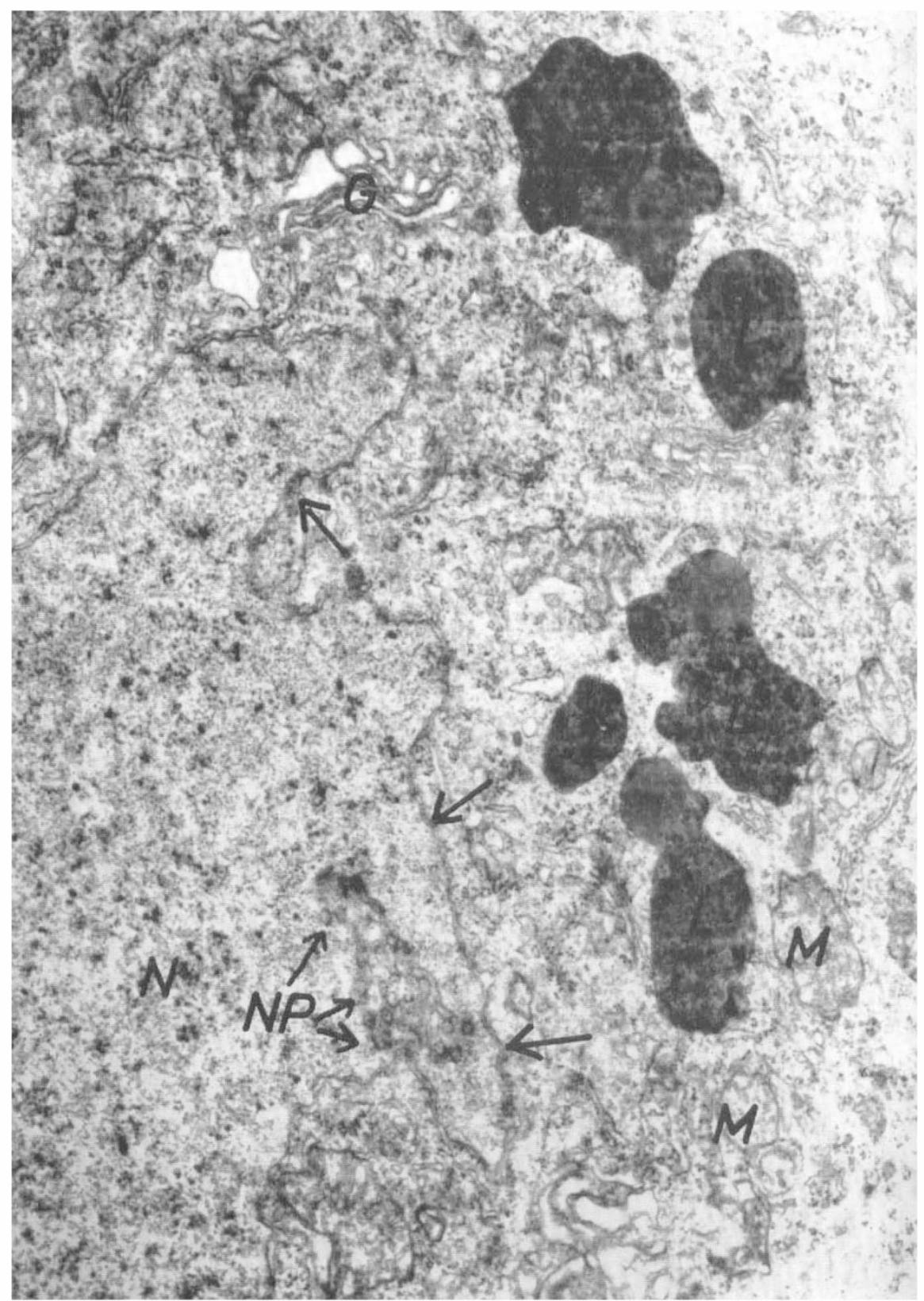

FIG. I2

Portion of large neurone (rat cerebral cortex) $\mathrm{N}=$ nucleus. Arrows mark double nuclear membrane, NP indicates a tangential section through the nuclear membrane and shows the nuclear pores of this membrane marked by arrows through which metabolic exchange between nucleus and cytoplasm takes place. $\mathrm{G}=$ golgi-apparatus, $\mathrm{L}=$ lysosomes. 


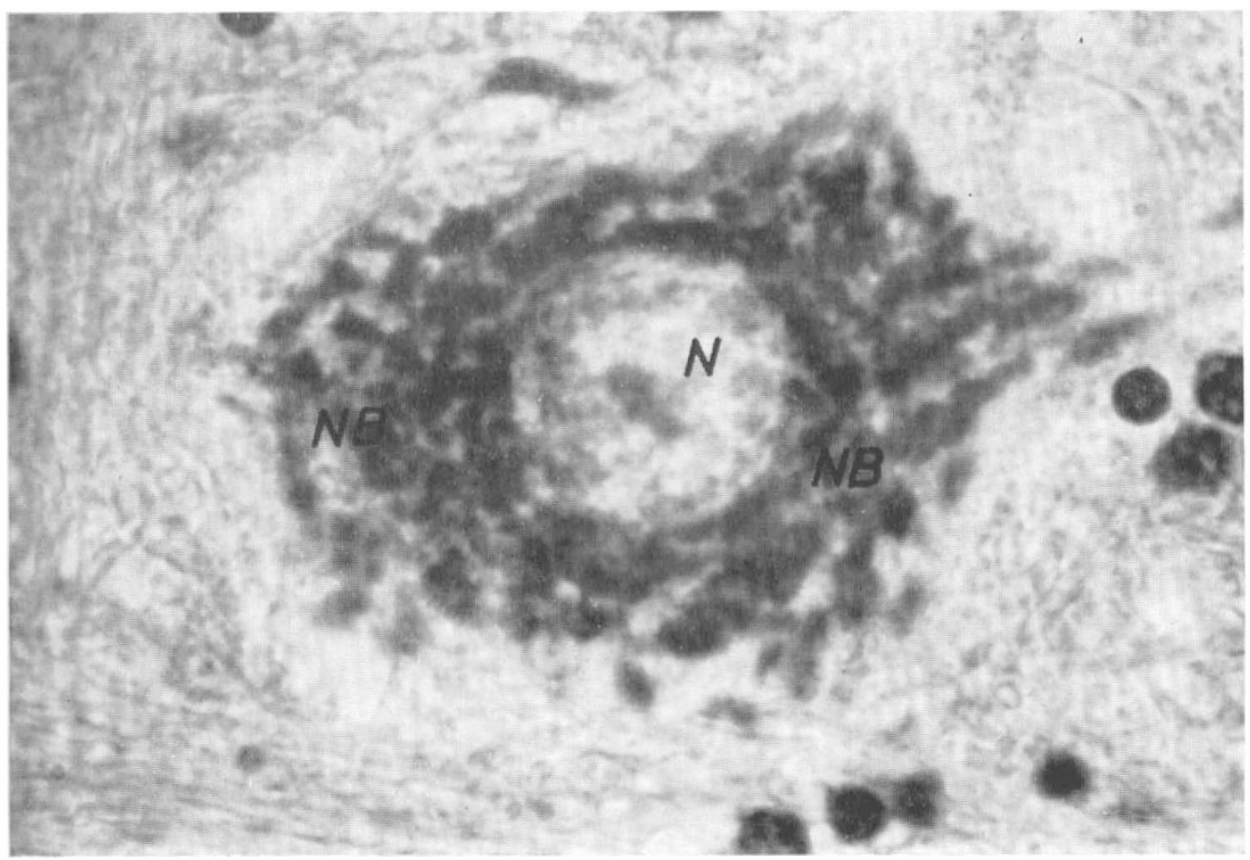

FIG. I3

Spinal motoneurone (Monkey) illustrating the dense arrangement of Nissl-bodies (NB), $\mathbf{N}=$ nucleus, fixation by formalin perfusion. The finer histology of individual Nissl-bodies, when seen under the electronmicroscope is shown in Figure 15.

\section{ACKNOWLEDGMENTS}

We would like to express our thanks to the Wellcome Trustees, London, the National Multiple Sclerosis Society, New York, grant No. 259-3, and the Deutsche Forschungsgemeinschaft, Bonn, who support various aspects of the investigations presented here. We would like to acknowledge the help of Frau M. Bothe, Frl. G. Hohmann, for drawings and microphotographs, Frl. Ch. Kiele, Frl. E. Möhring, and Frl. I Mende for their technical assistance in electronmicroscopy.

\section{SUMMARY}

The recent electronmicroscopical progress on the finer structure of nerve cells and synapses has been reviewed. To illustrate this progress the Purkinje-cells of the cerebellum and the motoneurone of the spinal cord have been selected.

The structure of Nissl-bodies and other organelles of the nerve cell such as a Golgi-complex, mitochondria, lysosomes and ribosomes, has been discussed.

Special emphasis has been paid to synaptic structures in order to relate observations made in light microscopy to electronmicroscopy. For this reason the development of synapses based on studies has been described and the significance of their degenerative alterations in experimental material discussed. 


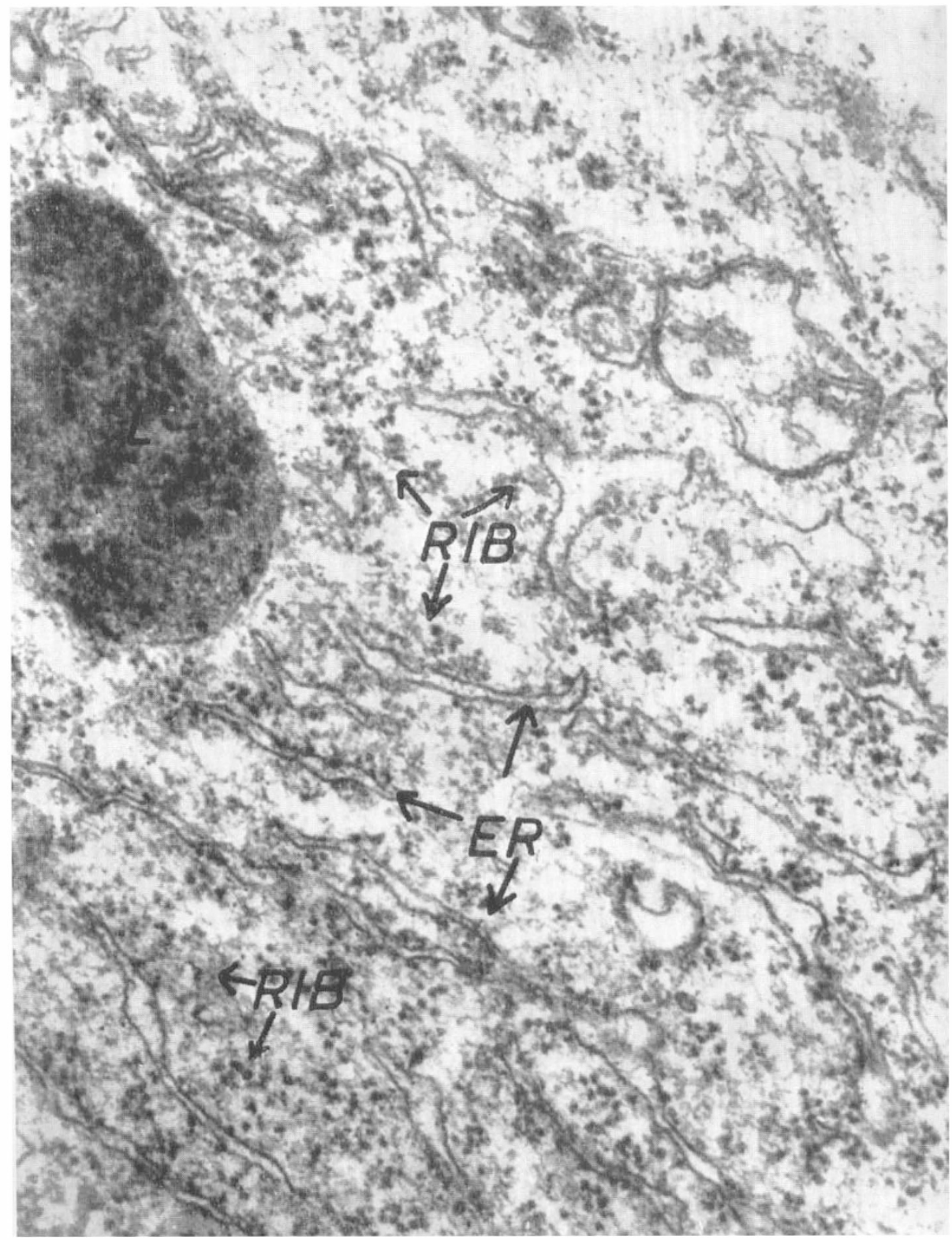

FIG. I4

Portion of a large cortical neurone to show the relationship of endocellular reticulum $=\mathrm{ER}$ and ribosomes $=\mathrm{RIB}$. 
THE FINER STRUCTURE OF SYNAPSES AND NEURONES

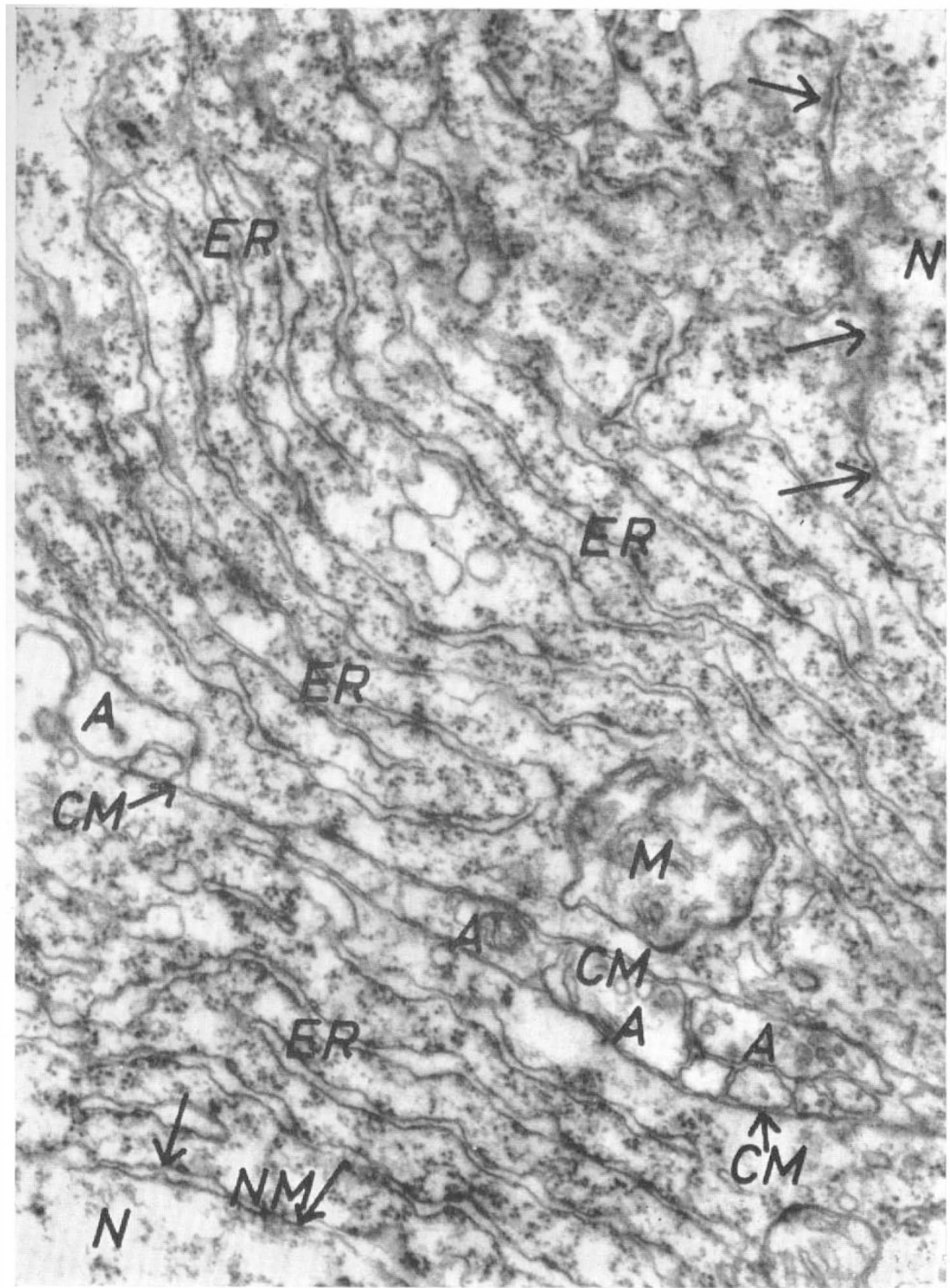

FIG. I5

Portions of two large spinal neurones separated by cell membrane (CM) between these two cells very fine axons pass (A). Note the laminated construction of the Nissl-bodies, separated here by a mitochondrium (M). ER=endoplasmatic reticulum, covered by ribosome granules which forms the subunits of a Nissl-body. $N=$ nucleus, $N M=$ nuclear membrane. The upper right arrows indicate the tortuous course of a nuclear membrane. 


\section{RÉSUMÉ}

Les auteurs rapportent les progrès apportés par la microscopie électronique ces dernières années, surtout en ce qui concerne la structure intime des cellules nerveuses et des synapses. Comme exemple on peut choisir les cellules de Purkinje du cervellet et les moto neurones de la moëlle.

Les structures intimes de corps de Nissl et d'autres organes comme le complex de Golgi, mitochondries, lysosomes et ribosomes sont finement décrits.

On considère particulièrement la structure normale et pathologique des synapses. Les connaissances actuelles au sujet des synapses et eleurs dégénérescences après traveaux expérimentaux que présente le travail de les auteurs sont résumées.

\section{ZUSAMMENFASSUNG}

Die Verfasser berichten über die Fortschritte, die die Elektronenmikroskopie in den letzten Jahren, vor allem auf dem Bereich der inneren Struktur der Nervenzellen und der Synapsen gemacht hat. Als Beispiele werden die Purkinje-Zellen des Kleinhirns und die Motoneurone des Rückenmarks ausgewählt.

Die Feinstruktur der Nissl-Körper und anderer Zellorgane, wie Golgi-Komplex, Mitochondrien, Lysosomen und Ribosomen, sind eingehend besprochen.

Besonders berücksichtigt wird die Struktur der normalen und pathologisch veränderten Synapse. Die jetzigen Kenntnisse über die Entwicklung der Synapsen und ihre Degenerationen nach experimentellen Eingriffen, die das Arbeitsprogramm der Verfasser darstellen, werden kurz zusammengefasst.

\section{REFERENCES}

Bellaris, R. (1959). F. Embryol. exp. Morph. 7, 94.

Bodian, D. (I 942). Physiol. Rev. 22, I46.

Bowsher, D., Brodal, A. \& Walberg, F. (I960). Brain, 83, I5O.

Brodal, A. \& Grant, G. (1962). Exp. Neurol. 5, 67.

Colonnier, M. \& Gray, E. G. (I962). Proceedings of the 5th International Congress for Electron Microscopy. New York: Academic Press.

Duncan, D. (1957). Tex. Rep. Biol. Med. 15, 367.

EICHNER, D. (1956). Z. Zellforsch. 43, 501 .

EsCHNER, J. \& GleEs, P. (I 963). Seperatum Experientia, 19, $30 \mathrm{I}$.

Fox, C. A. \& BARNARD, L. N. (I957). F. Anat. (Lond.), 91, 299.

GleES, P. (I96I). Springer-Verlag I96I.

- (196I). Experimental Neurology. Oxford: Clarendon Press.

- (1961). Dtsch. med. Wschr. 86, I1 75.

- (1963). Dtsch. Z. Nervenheilk. 184, 607.

Glees, P. \& Nauta, W. J. H. (I955). Mschr. Psychiat. Neurol. 129, 74.

Glees, P., Pearson, C. \& Smith, A. G. (I958). Quart. F. exp. Physiol. 43, 52.

GleEs, P. \& EsChNER, J. (I962). Umschau 435.

Glees, P., HallermanN, W. \& Naeve, H. (I964). Die Representation retinaler Abschnitte im Corpus geniculatum laterale des Affen. (Submitted for publication.)

Glees, P. \& Sheppard, B. (I 964). Z. Zellforsch. (In Press.)

- (1964). Z. Zellforsch. (In Press.)

Gray, E. G. (I96I). Ultrastructure of Synapses of the Cerebral Cortex and of Certain Specialisations of Neurological Membranes. Electron Microscopy in Anatomy, p. 54. London: Arnold.

Gray, E. G. (1962). Proceedings IV Internationaler Kongress für Neuropathologie, p. 57 ed. Jacob, H. Stuttgart: Thieme.

Gray, E. G. \& Whittaker, V. P. (1960). F. Physiol. (Lond.), I53, 35.

Gray, E. G. \& Hamlyn, L. H. (1962). F. Anat. 96, 309.

GuIlleRY, R. W. (1964). Lecture on the International Summer School of Brain Research. Amsterdam.

HeRndon, R. M. (1963). F. biophys. biochem. Cytol. 18, 167.

HonjIn, R. (I956). Okajimas Folia anat. jap. 29, II 7.

HoRstMANN, E. (I957). Dtsch. med. Wschr. 18, 73 I.

Hyden, H. (I96I). The Neuron. In The Cell, vol. 4, p. 2 I 5 ed. Brachet, J. \& Siekevicz P., New York: Academic Press. 
LACY, D. (1957). F. biophys. biochem. Cytol. 3, 779.

LIDDELL, E. G. T. (I960). The discovery of Reflexes. Oxford: Clarendon Press.

Meller, K. (1964). Proceedings of the 3rd European Regional Conference of Electron Microscopy Prague. (In Press.)

Niessing, K. L. \& Vogell, W. (I960). Z. Zellforsch. 52, 2 I6.

Palade, G. E. (I955). F. biophysic. biochem. Cytol. 2, 59.

Palade, G. E. \& Siekevicz, P. (I956). F. biophys. biochem. Cytol. 2, I7I.

Palay, S. L. (1958). Exp. Cell Res. Suppl. 5, 275.

Palay, S. L. \& Palade, G. E. (I955). F. biophys. biochem. Cytol. I, 69.

RAMON y CAJAL (1952). Histologie du Systéme nerveux. Madrid: Instituto Ramón y Cajal.

Schmit, F. O. (1957). Cell. Comp. Physiol. Suppl. I, 49, I65.

SMITH, S. W. (1959). f. biophys. biochem. Cytol. 6 (I), 77.

SOtelo, J. R. \& TRUjILlo-Cenóz, O. (I958). Z. Zellforsch. 49, I-I2.

Tennyson, V. M. (1962). Proceedings 5th International Congress Electr. MIC. vol. 2, n. 8, New York: Academic Press.

Thomas, O. L. (1960). Nature (Lond.), 185, 703.

ThORNBURG, W. \& DE RoberTis, E. (I956). F. biophys. biochem. Cytol. 2, 475.

VAN DER LOOS, H. (1963). Z. Zellforsch, 60, 815.

WeChSLER, W. \& MELlER, K. (1963). Naturwissenschaften, 23, 7I4.

WeChSleR, W. \& Meller, K. (I963). Acta Neuropathol. (Berl.), 2, $49 \mathrm{I}$.

WeCHSLER, W. \& MELLER, K. (1963). Naturwissenschaften, 22, 694.

WhitTaker, V. P. \& Gray, E. G. (1962). Brit. med. Bull. 18, (3), 223.

Zeigel, R. F. \& Dalton, A. J. (I962). F. biophys. biochem. Cytol. 15, 45. 